\title{
Polyphenol Content and Enhancing Plant resistance of Lowland Arabica Coffee
}

\author{
Distiana Wulanjari ${ }^{1}$, Ketut Anom Wijaya ${ }^{1}$, Muhammad Ghufron Rosyady ${ }^{1}$ and Ali Wafa ${ }^{2 *}$ \\ ${ }^{1}$ Agricultural Science Departement, Faculty of Agriculture, University of Jember 68172, Indonesia \\ ${ }^{2}$ Plant Protection Departement, Faculty of Agriculture, University of Jember 68172, Indonesia
}

\begin{abstract}
The production of arabica coffee in Indonesia is still low because of leaf rust disease suppression caused by Hemileia vastatrix. Basically, it can produce well in the overlapping zone (1000-1500 masl). This potential can be used as basic for intensifying arabica coffee cultivation to the lowland. For anticipation steps to reduce the spread of leaf rust can be done by increasing the production of polyphenol as plant resistance. The addition of mineral element such as silica, boron, iodine, calcium, and potassium can stimulate the synthesis of plant polyphenol. In this research, five minerals above were tested into 7 treatment with single factor RCBD, that is without additional of the mineral element, $150 \mathrm{mg} \mathrm{L}^{-1} \mathrm{Si}, 300 \mathrm{mg} \mathrm{L}^{-1} \mathrm{~B}, 3000 \mathrm{mg} \mathrm{L}^{-1} \mathrm{Ca}, 20.000 \mathrm{mg} \mathrm{L}^{-1} \mathrm{~K}, 300 \mathrm{mg} \mathrm{L}^{-1} \mathrm{I}$, and the combination/mix of five mineral elements. The laboratory analysis shows that calcium able to produce the highest polyphenol, but it is not a real difference with silica. The polyphenol that synthesized by $\mathrm{Si}, \mathrm{I}$, and $\mathrm{K}$ was able to reduce the leaf rust incidence until $78,13 \%$, while $\mathrm{Ca}$ can reduce the incidence up to $71,88 \%$.
\end{abstract}

\section{INTRODUCTION}

Arabica coffee cultivation in Indonesia is on limited highland $(1000 \mathrm{~m}$ asl). It caused arabica coffee productivity in Indonesia still low. In 2008 the area of arabica coffee cultivation in Indonesia was only $26,9 \%$ of the total area of coffee plantations [1]. The aim of the cultivation of arabica coffee in the highland is to suppress the spread of leaf rust disease caused by fungus Hemileia vastatrix. Arabica coffee can be planted and produce well in overlapping zones, between 1000-1500 $m$ ASL [2]. The intensification of Arabica Coffee in the lowlands area has several consequences. Including the decrease in production due to increased leaf rust disease [3]. In the lowland (temperatures between $21^{\circ} \mathrm{C}-24^{\circ} \mathrm{C}$ ) $\mathrm{H}$. vastatrix spore develop faster. The leaf rust disease in America can reduce arabica coffee production due to poor crop management. It causes the emergence of new pathological and physiological races [3].

The effort to intensify the arabica coffee to the lowland needs to balance with increasing plant resistance. Some agronomic efforts can apply to induce plant resistance. One of them is through the addition of mineral elements. Theoretically, it capable of inducing the plant resistance. Some elements such as silica, boron, iodine, calcium, and potassium have difference mechanisms to enhance the plant resistance of plants. Silica has a mechanism to strengthen the cell wall by forming layers composed of silica polymers and integrating with calcium and pectin.

\section{MATERIAL AND METHODS}

This experiment carried out by using arabica coffee plant in the productive phase that planted at an altitude of 460 masl. The five minerals tested in seven treatments with single factor RCBD. That is without additional mineral element (control), $150 \mathrm{mg} \mathrm{L}^{-1} \mathrm{Si}, 300 \mathrm{mg} \mathrm{L}^{-1} \mathrm{~B}, 3000 \mathrm{mg}$ $\mathrm{L}^{-1} \mathrm{Ca}, 20.000 \mathrm{mg} \mathrm{L}^{-1} \mathrm{~K}, 300 \mathrm{mg} \mathrm{L}^{-1} \mathrm{I}$, and the combination/mix of five mineral elements. The solution is applied foliar using mist sprayer placed under the surface of the leaf. The application of mineral elements is carried out 5 times with the time interval once every 7 days. After the last application, the plants incubated for 30 days. The treatment response observed through the variable polyphenol content, decreased incidence of disease, and lignin content. If the treatment showed a significantly different response, then the data analysis was continued using DMRT at 95\% significance level.

\section{RESULT AND DISCUSSION}

The biggest problem in arabica coffee that grown in the lowland area is the leaf rust attack by the fungus $H$. vastatrix. Various sources said the leaf rust can reduce production up to $80 \%$, so to cultivate the arabica coffee in the lowland requires specific treatment to increase its plant resistance. One of the plant resistance of plants to attack a disease controlled through the production of secondary metabolites. Need great effort to boost the Secondary metabolites molecule such as polyphenols. In

\footnotetext{
*Coresponding author : distiana.faperta@unej.ac.id
} 
line with that, polyphenol can increase plant resistance against leaf rust disease. Polyphenols are aromatic chemical compounds that have many phenol groups, consisting of simple phenols, menolic acids, phenyl propenoids, coumarin, flavonoids, and tannins. Some elements can stimulate higher polyphenol production while the plants at the stress condition. The results of showed that calcium was able to induce the formation of the highest polyphenol untill1,72 $\mathrm{mg} \mathrm{g}^{-1}$, but it was not significantly different from silica with an average of $10,98 \mathrm{mg} \mathrm{g}^{-1}$. The polyphenol were induced by calcium three times higher than the average of control, which only $3,28 \mathrm{mg} \mathrm{g}^{-1}$.

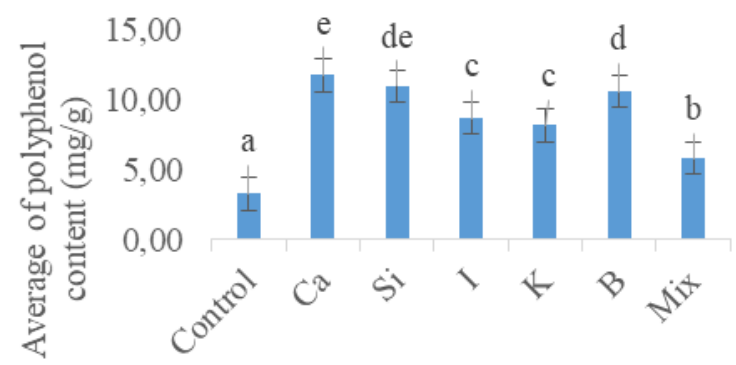

Mineral element type

Fig. 1. The polyphenol content's on lowland arabica coffee leaves

The primary mechanism of calcium for enhancing plant resistance is through the formation of calcium pectate bonds in the middle lamella and make the cell stronger. On others, calcium also binds the ROS and becomes the center of a hypersensitive reaction that leads to programmed cell death (PCD), [4]. Another calcium mechanism was able to increase plant resistance such as induce polyphenol production. Polyphenol content can influence disease incidence. It means the amount or percentage of disease in each plant individual regardless of the severity that occurs in one individual plant. The disease incidence has decreased from the addition of calcium reached $71,88 \%$.

Not significantly different from above, by silica addition, the polyphenol content reached $10,98 \%$. Silica was also able to reduce the incidence of leaf rust in lowland arabica coffee up to $78,13 \%$. The production of polyphenols and decreasing the disease incidence produced by silica minerals do not differ significantly from the results of calcium. Silica produces the silica polymers in the epidermis cell wall of plants. The cellulose layer in plant epidermis tissue is also associated with silica polymers. The double-layer formed, which causes plant epidermal tissue to become thicker and stiffer. Hypothetically, it makes $H$. vastatrix challenging to penetrate the hyphae of fungus. Plant resistance can suppress the proliferation of fungal growth. It resulted in a lower incidence of leaf rust disease. Silica synthesized polyphenols occur after mechanical resistance is formed. The presence of polyphenols (produced by silica) further increases plant resistance to the spread of leaf rust disease so that it can reduce the incidence up to $78,13 \%$ (Fig. 2).

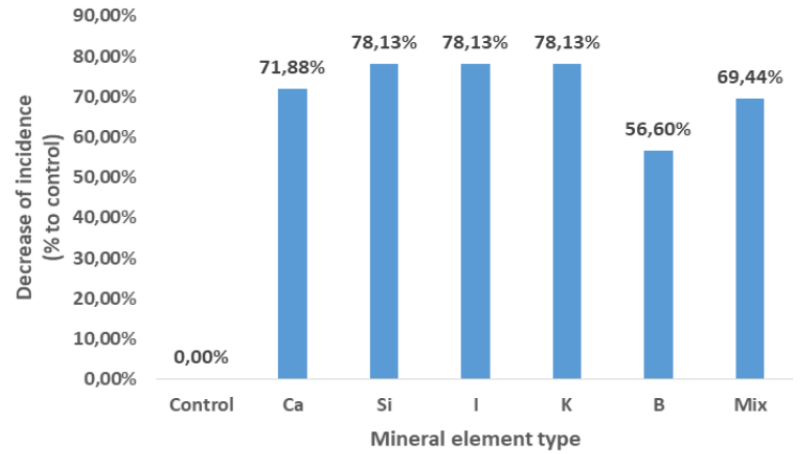

Fig. 2. Decrease incidence of rust in lowland arabica coffee leaves

The iodine and potassium were induced the polyphenol synthesis in plant inversely proportional to the decrease disease incidence. The polyphenol content induced by both mineral are $8,65 \mathrm{mg} \mathrm{g}^{-1}$, and $8,15 \mathrm{mg} \mathrm{g}^{-}$ ${ }^{1}$, respectively, nor the reduction in disease incidence is $78,13 \%$. The Iodine addition for synthesizing polyphenols became one mechanism of plant resistance among another resistance pathway. This mineral is also capable of being the antibiotic. The Potassium has a potential role in increasing plant resistance besides as secondary metabolite precursor. It includes the behavior of Potassium was acted as an enzyme cofactor and helps absorb nutrients. With better nutrients absorption by plants, it became better to adapt to biotic stresses.

Polyphenols in plants have sensitive regulation when plants are stressed. Polyphenols synthesized on the shikimate pathway during stress conditions. On that condition, the polyphenols are oxidized by the phenylalanine ammonia-lyase (PAL) enzyme through the phenolic pathway. This activity causes plants to become more resistant [5]. This hypothesis can explain that the polyphenols which synthesized by iodine and potassium are lower than other minerals. The mechanisms of iodine in increasing the plant resistance of plants through polyphenol synthesis is undergoing an overhaul when the stress occurs.

The increasing of total polyphenol due to the accumulation of iodine in the plant tissue, accelerate the polymerization of glucose into cellulose to strengthen the cell wall. Increase the strength and elasticity of cell wall through the middle lamella by calcium, and various other mechanisms. A stronger cell wall faced the plant's became stronger for $H$. vastatrix fungus infection.

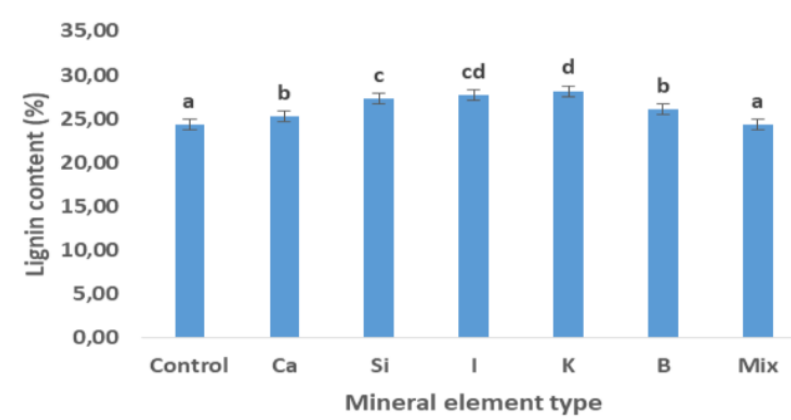

Fig. 3. Percentage of lignin content of lowland arabica coffee leaves 
Polyphenols' role for increasing plant resistance can be seen in the formed lignin content. In the plant cell walls, lignin is a polymer compound from the series of phenol groups. According to [6] lignin can limiting the fungal infection. Figure 3 shows the amount of lignin in leaf tissue samples of lowland arabica coffee plants. The result showed that the lignin content in plant samples stimulated by silica, iodine, and potassium was not significantly different and had the highest percentage $27,31 \% ; 27,73 \%$; and $28,15 \%$ respectively. The woody material (lignocellulose) consists of the lignin, cellulose, hemicellulose and other extractive substances [7]. The other extractive substances are very possible to be classified into lignin because the structure of their compounds is almost similar to the lignin component. The amount of lignin contained causes tissue to be thicker, stiffer, and difficult to be penetrated by microorganisms (include $H$. vastatrix hyphae), so that the plant resistance can be increased.

\section{CONCLUSION}

The polyphenol content were stimulated by the mineral elements calcium, silica, iodine, and potassium can reduce the incidence up to $78,13 \%$. The escalation of the resistance level on lowland arabica coffee during leaf rust disease infection can be done by mineral adding.

\section{CONCLUSION}

To Project Implementation Units of Islamic Development Bank- The University of Jember and Research and Social Service Bureau (LP2M) University of Jember, for the multi-years Research Grand with Contract Number 3222/UN25.3.1/LT/2019. From 2017 until 2019.

\section{References}

1. Direktorat Jendral Perkebunan. Statistik Perkebunan Indonesia 2015-2017 Kopi. Dirjen PerkebunanKementerian Pertanian (2016)

2. Woku et al. 2015. Food Research International 105 (2018): 278-285.

3. H.V.D.Vossen, B. Bertrand, and A. Charrier. 2015. Euphytica 204.2 (2015): 243-256

4. V. Demidchik and S. Shabala. 2018. Functional Plant Biology. Functional Plant Biology 45.2 (2018): 9-27.

5. E. Proklamaningsih, I. Budisantoso, I. Maula... Biologi 12 1:96-102 (2019)

6. Bennett, Alison E., et al. 2015. New Phytologist 206.1: 166-174.

7. H. Suryanto. 2016. Artikel. 1-14 